TAO, Vol. 16, No. 3, 531-545, August 2005

\title{
Geophysical Well Log Study on the Paleoenvironment of the Hydrocarbon Producing Zones in the Erchungchi Formation, Hsinyin, SW Taiwan
}

\author{
Jinder Joseph Chow ${ }^{1, *}$, Ming-Chung Li ${ }^{1}$ and Shi-Chie Fuh ${ }^{2}$
}

(Manuscript received 1 June 2004, in final form 10 May 2005)

\begin{abstract}
Gamma ray log facies of nine wells were used to reflect the vertical profile of grain size and were combined with well sample data to deduce the paleoenvironment of the Erchungchi " $A$ " Member in the Hsinyin and Pachanchi areas. Four log facies were recognized in the studied intervals: a thick funnel-shaped facies representing a prograding delta; a thin funnelshaped facies representing a crevasse splay; a boxcar-shaped facies representing a distributary channel; a bell-shaped facies representing a fluvial or deltaic channel. The paleoenvironment of the Erchungchi " $A$ " Member in the Hsinyin area is mainly an imbricated delta system whose thickest lobe is located in Well S-1. The delta was first deposited in the headstreams of the submarine channels, followed by mudstones as cap rocks which seal hydrocarbons in stratigraphic traps. There are many submarine channels in southwestern Taiwan, so similar stratigraphic hydrocarbon trap conditions may occur elsewhere in southwestern Taiwan.
\end{abstract}

(Key words: Well log, Hsinyin, Hydrocarbon, Paleoenvironment)

\section{INTRODUCTION}

During the 1970's, the Chinese Petroleum Corporation (CPC) discovered commercial hydrocarbons in the Chiayi and Tainan areas, resulting in considerable attention and resources being focused on gas exploration in the region. In April 1981, the shallow Pleistocene Erchungchi "A" Member in Hsinyin Well No. 1 produced natural gas at a rate of 26,600 $\mathrm{m}^{3}$

\footnotetext{
1 Institute of Applied Geophysics, National Taiwan Ocean University, Keelung, Taiwan, ROC

2 Exploration \& Development Research Institute, Chinese Petroleum Corporation, Miaoli, Taiwan, ROC

* Corresponding author address: Prof. Jinder Joseph Chow, Institute of Applied Geophysics, National Taiwan Ocean University, Keelung, Taiwan, ROC; E-mail: jdchow@ms24.hinet.net
} 
per day. This hydrocarbon discovery in the shallow formation suggests great potential in the Erchungchi "A" Member.

Geochemical analysis revealed that the hydrocarbons of the Erchungchi "A" Member are biogenic (Chow et al. 1986; Fuh et al. 1997). Of the 7 exploratory wells in the Hsinyin area, hydrocarbons produced in Wells S-1, S-2 and S-3 prompted several petroleum geology research projects on the shallow strata because of low exploration costs. Chow et al. (1986, 1987, 1988) conducted research on hydrocarbon potential in the Hsinyin and Tainan areas based on seismic data which delineanted the stratigraphic features of submarine channels in the areas. Fuh et al. $(1996,1997)$ studied seismic inversion, thin-bed effect analysis and the probable form of stratigraphic sealing in the Hsinyin gas field. Fuh et al. (1996) suggested that the Hsinyin gas field is a stratigraphic trap, but not a structural trap.

Log interpretation is no longer limited to an estimation of hydrocarbon reserves; it is even more powerful for revealing stratigraphical paleoenvironments (Kessler 1995; Saner 1995; Bourquin 1998; Milana 2000; Murkute 2001). Sediments in different paleoenvironments display characteristic log motifs. As a result, borehole logs are widely used to interpret paleoenvironments (Daniels et al. 1983; Selly 1978; El-Gendy and El-Din Saleh 1988; Prensky 1989; Bischke 1994).

The different logs currently available for study of the paleoenvironment of the Erchungchi "A" Member in the Hsinyin area are spontaneous potential logs (SP), resistivity logs, gammaray logs, and lithological data of Wells S-1, S-2, S-4, S-5, S-6 and S-7. In the Pachanchi area, Wells P-5, P-6 and P-7 were selected in accordance with current available data and spatial distribution (Fig. 1).

Even though from Fuh et al. (1996) the trap type of the Hsinyin gas field can be recognized as stratigraphic, the paleoenvironment of the Erchungchi " $A$ " Member in the Hsinying area still remains an unsettled question. This paper attempts to present a paleoenvironmental model of the hydrocarbon-producing zone based on a geological study of well logs from the Hsinyin area.

The Pachanchi gas field is only $15 \mathrm{~km}$ away from the Hsinyin gas field. The Erchungchi Formation in the Hsinyin gas field produces petroleum; however, the Pachanchi gas field shows no hydrocarbon in the corresponding formation. This disparity will also be examined.

\section{STRATIGRAPHY}

The foothill belt in southwest Taiwan primarily consists of strata from the Miocene to Pleistocene series, with obvious lithological change from north to south and west to east. In addition, other research has been conducted in the study area, including micropaleontology (Chi 1981; Huang 1984; Wu 1984; Huang 1987), paleomagnetism (Hong 1991), sedimentology (Wu and Wang 1989; Lin 1991), and seismic stratigraphy (Chow 1986, 1987; Fuh 1997, 2003). Chang (1962) established a stratigraphic system of the Tsengwenchi profile in the study area. The biostratigraphic and lithostratigraphic correlations in southwest Taiwan are shown in Table 1. Micropaleontology research (Chi 1981; Huang 1984; Wu 1984; Huang 1987) indicates that the boundary between the Pliocene and the Pleistocene is located in the lower 
Gutingkeng Formation and Liuchungchi Formation. Most sedimentology research suggests that the paleo-depth of the paleoenvironment to the south of the Tsengwenchi profile is deeper than that to the north, and that from north to south the paleoenvironments cover littoral facies to continental slope (Wu and Wang 1989; Lin 1991; Yan and Hong 1994).

\section{LOG FACIES}

Studies of modern sedimentary environments (Selly 1985; Murkute 2001) reveal that vertical profiles of grain size from a specific environment have certain characteristics. For instance, prograding deltas and barrier bars deposit upward-coarsening grain size profiles. Grain size

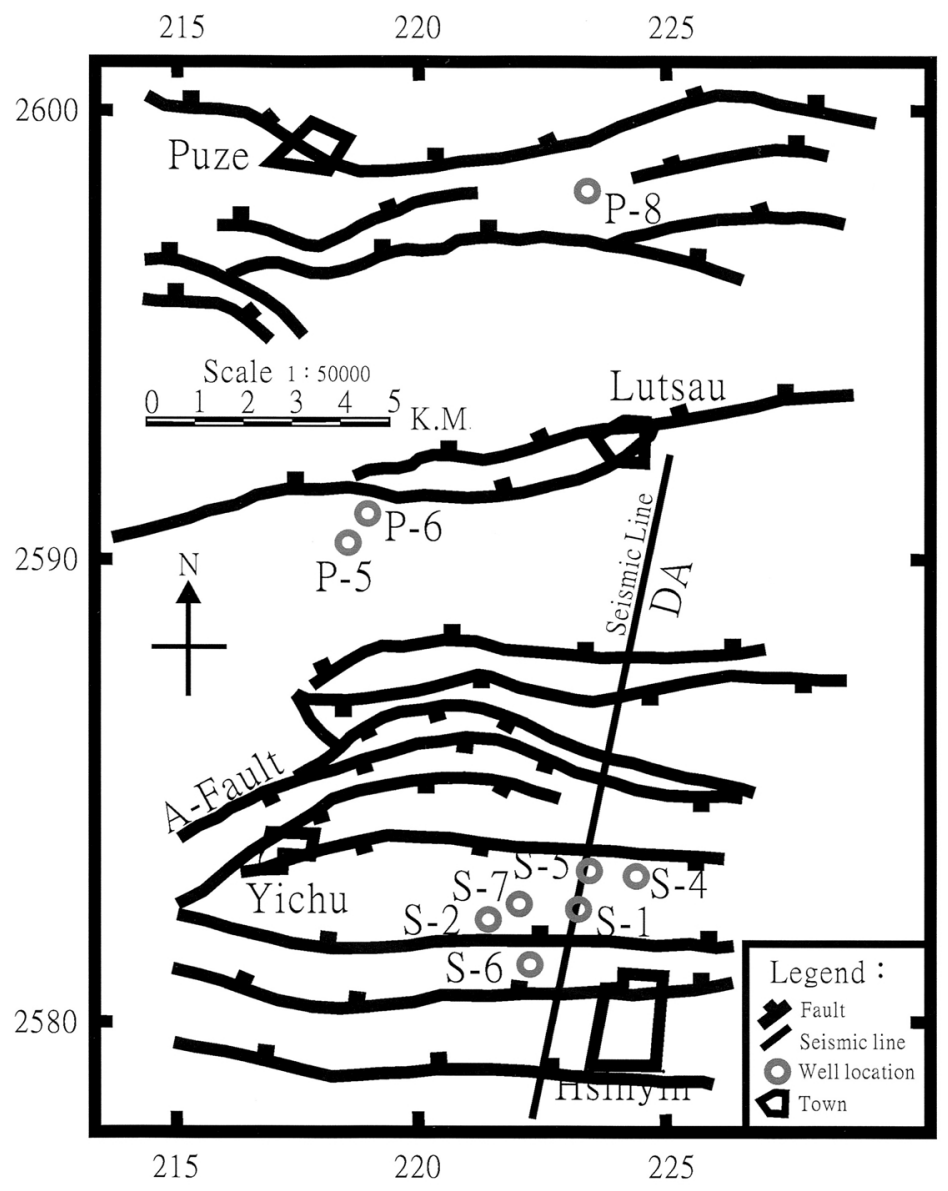

Fig. 1. Location of well site and seismic profile in study area. Hsinyin area: S-1, S-2, S-4, S-5, S-6 and S-7. Pachanchi area: P-5, P-6 and P-8. Seismic profile DA. 
Table 1. Biostratigraphical and lithostratigraphical correlation (Modified from Chi 1981).

\begin{tabular}{|c|c|c|c|c|c|}
\hline EPOCH & $\begin{array}{l}\text { NANNO } \\
\text { FOSSILS }\end{array}$ & $\begin{array}{l}\text { Chiayi } \\
\text { (Yunshuichi) }\end{array}$ & $\begin{array}{l}\text { Tainan } \\
\text { (Tsengwenchi \& }\end{array}$ & \multicolumn{2}{|c|}{$\begin{array}{l}\text { Kaohsiung } \\
\text { (Kuanmiao \& Kaitzuliao) }\end{array}$} \\
\hline \multirow{8}{*}{ Pleistocene } & NN20 & \multirow[t]{2}{*}{ Liushuang Fm. } & \multirow[t]{2}{*}{ Liushuang Fm. } & \multirow[t]{2}{*}{ Liushuang Fm. } & \\
\hline & NN19 & & & & \multirow{7}{*}{$\begin{array}{l}\text { Lingkou } \\
\text { Conglomerate }\end{array}$} \\
\hline & & Erchungchi Fm. & \multirow[t]{2}{*}{ Erchungchi Fm. } & $\begin{array}{l}\text { Upper } \\
\text { Gutingkeng Fm. }\end{array}$ & \\
\hline & & A Mem. & & \multirow{12}{*}{$\begin{array}{l}\text { Lower } \\
\text { Gutingkeng Fm. }\end{array}$} & \\
\hline & & \multirow{2}{*}{ Kanhsialiao Fm. } & Yuching Sh. & & \\
\hline & & & Chingmen S.S. & & \\
\hline & & & \multirow[b]{2}{*}{ Peiliao Sh. } & & \\
\hline & & Liuchungchi Fm. & & & \\
\hline \multirow{7}{*}{ Pliocene } & NN18 & & & & \multirow{4}{*}{ Nanshihlun Ss. } \\
\hline & & \multirow[t]{2}{*}{ Yunshuichi Fm. } & & & \\
\hline & NN15 & & Chutouchi Fm. & & \\
\hline & $\mathrm{NN} 14$ & Niantcui $\mathrm{Fm}$ & Maopu Sh. & & \\
\hline & & & Ailiacchiao Fm. & & Kaitzuliao Sh. \\
\hline & NN12 & & & & \\
\hline & & & Yenshuikeng Sh. & & \\
\hline & NN11 & Chunglun Fm. & & Mucha Fm. & Wushan Fm. \\
\hline Miocene & & & Tangenshan Ss. & & \\
\hline & $\begin{array}{l}\text { NN10 } \\
\text { NN6 }\end{array}$ & Nanchuang Fm. & $\begin{array}{l}\text { Changchihkeng Fm } \\
\text { Huanghuatzu Fm. } \\
\text { Sanmin Sh. }\end{array}$ & & \\
\hline
\end{tabular}

vertical profiles may also be of use in litho-facies analysis. The grain size vertical profiles in sand-shale sequences can be indicated by both SP and gamma ray logs. The deflection on SP $\log$ is controlled locally by permeability, with the maximum leftward deflection occurring in the position of maximum permeability. Permeability increases with grain size, except for highly cemented sandstone-shale sections. Therefore the SP log is usually a vertical electrical logging curve of grain size. Similarly, the gamma-ray log may reflect the vertical profile of grain size, as the clay content (and hence radioactivity) in sandstone increases with decline of grain 
size. Exceptions to this general statement may be caused by the presence of a conglomerate containing clay detritus, and anomalous radioactive minerals, such as glauconite, mica, and zircon. The trends denoted by the gamma ray logs and SP logs are approximately identical to the grain size profiles in the wells drilled in the Hsinyin area, indicating that the rock doesn't contain additional radioactive sediments. As the gamma-ray log is sensitive to sand-shale changes in rock formations, it is used as a primary analytical tool in this study.

No log motif is unique to a particular sedimentary paleoenvironment, but by combining an analysis of log motif with the composition of well-cutting samples, an interpretation of the paleoenvironment can be attempted (Selly 1985; Murkute 2001). Kessler and Sachs (1995) used gamma-ray logs and seismic characteristics to study the sedimentary process of sandstones of Ireland. Bourquin et al (1998) presented that the electrofacies from well logs correlate well with the sedimentary facies from core analysis, and the electrofacies established on well $\operatorname{logs}$ can be used to directly interpret the paleoenvironments of well formations.

Analysis using the downhole geological report, well logging properties, biostratigraphic data and stratigraphic correlation (Fig. 2) shows that the "A" member of Wells S-1, S-2, S-4, S-5, S-6 and S-7 in the Hsinyin area can be divided into four sections: Section 1, Section 2, Section 3 and Section 4. Stratigraphic correlation of Wells P-5, P-6 and P-8 (Fig. 3) in the Panchanchi area led to a division of the corresponding columns of the Erchungchi "A" Member into five sections: Section I, Section II, Section III, Section IV and Section V in this paper. Analysis of the logs indicates that the log motifs of the study area fall mostly into four categories: thick funnel-shaped, thin funnel-shaped, boxcar-shaped and bell-shaped.

\subsection{Thick Funnel-shaped Successions}

\subsubsection{Description}

The gamma-ray logs of Sections 1 and 2 in the wells of the Hsinyin area (Fig. 2) appear slightly serrated with a thick funnel shape mostly more than 30 meters thick. The thick funnel motif indicates coarsening or cleaning upwards of thick sediments. The geological reports of well-cutting samples reveal the lithologies of these two sections are sandstone. Carbonaceous detritus occur in these two sections of Wells S-4 and S-7. The only thick funnel-shaped log motif in the Pachanchi area occurs in Section V of Wells P-5 and P-6 (Fig. 3). Their thickness is $28 \sim 32 \mathrm{~m}$. Carbonaceous matters are also reported in Section V.

\subsubsection{Interpretation}

Glauconite, shell debris, carbonaceous detritus and mica are commonly recorded in well sample descriptions in well reports. Coupled with a study of log motifs, their presence (but not their absence) may aid the interpretation of the depositional paleoenvironment of sand bodies. This technique was first proposed by Selly $(1985,1998)$ and followed by many well-log researchers (e.g., Bourquin 1998: Murkute 2001). In an ideal world, facies analysis should be based on a detailed petrographic and sedimentological study of cores, but this method is not useful in regions where cores are not available. Since cores of our study area are not available or very few, we follow the paleoenvironment identification methods of Selly $(1985,1998)$. 


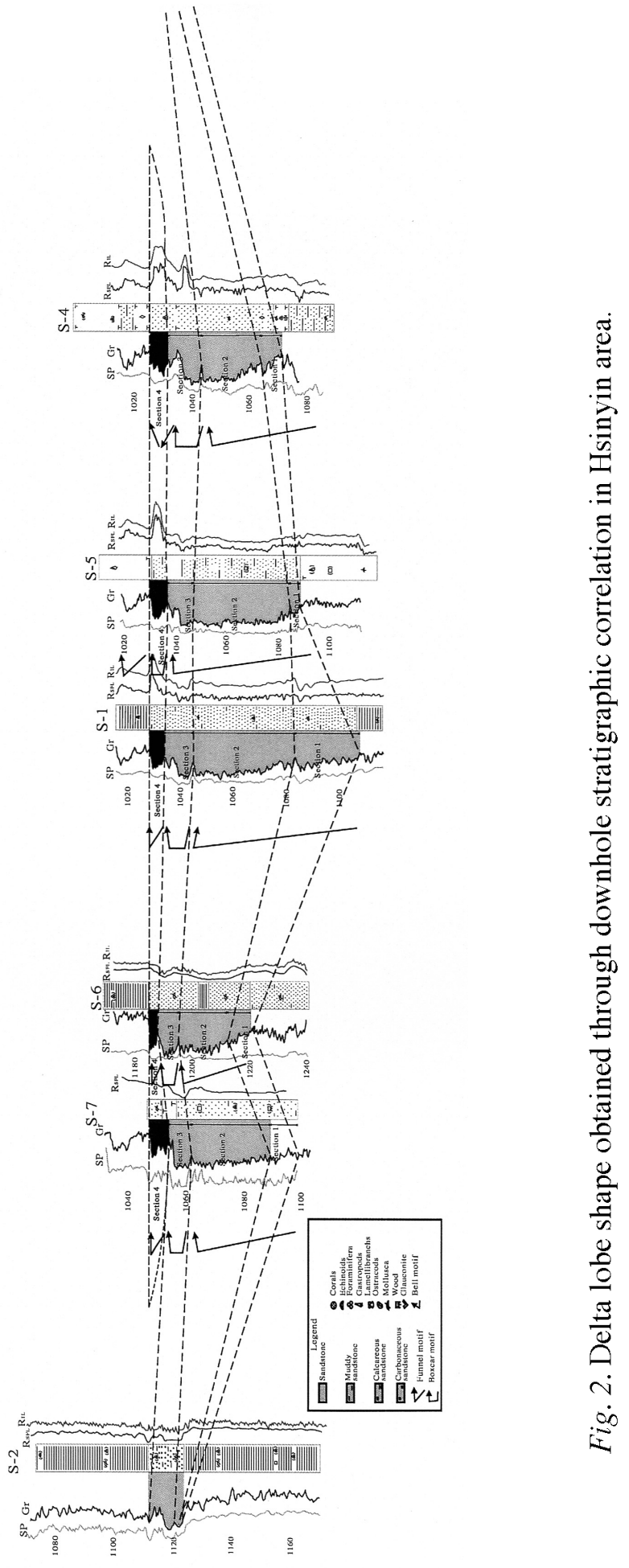




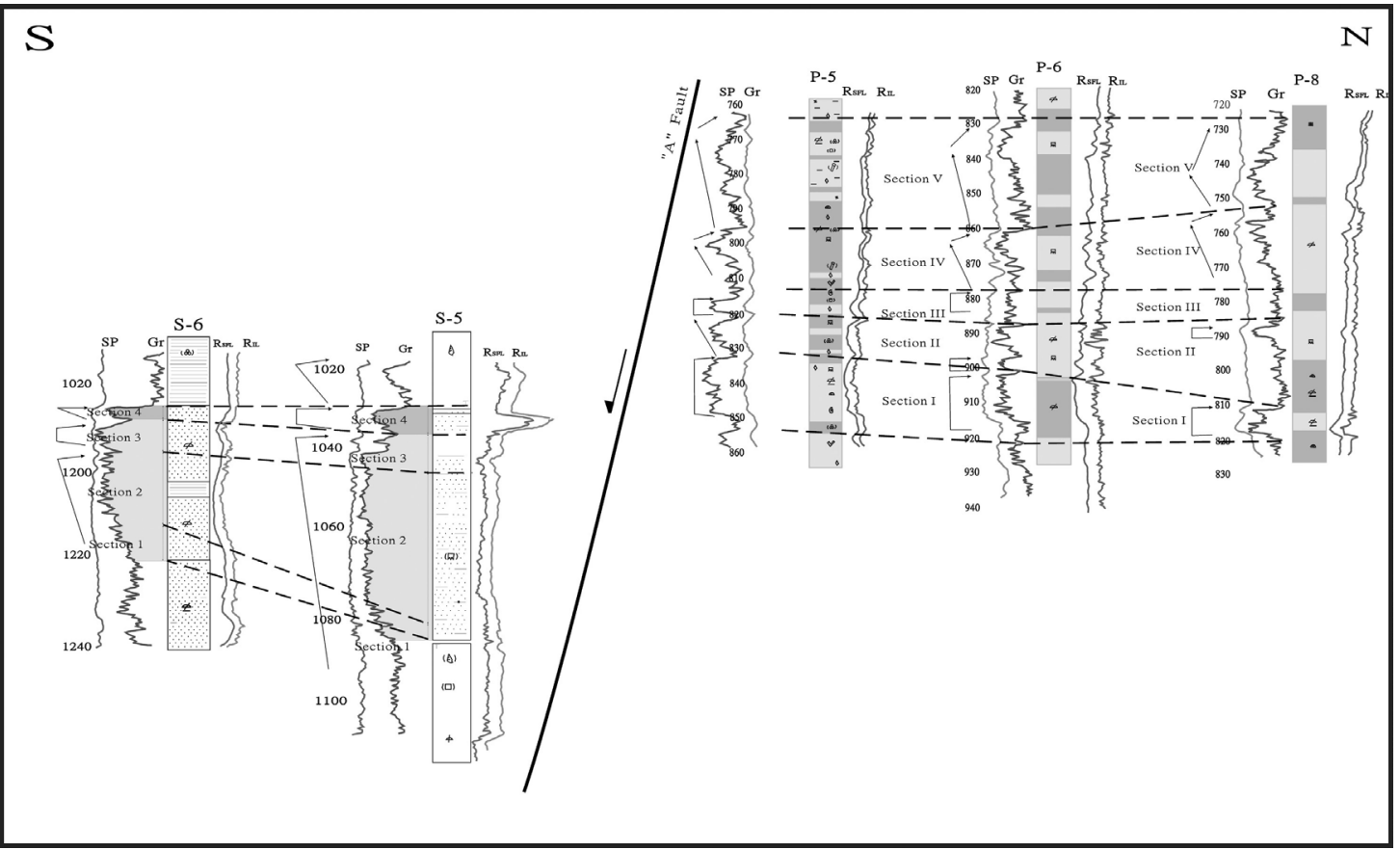

Fig. 3. Well log correlation of the Pachanchi and Hsinyin areas across "A" fault in north-south direction.

Carbonaceous detritus includes coal and plant fragments. The preservation of organic matter in rock generally indicates rapid deposition with minimal reworking and oxidation (Selly 1998).

The funnel-shaped successions with carbonaceous matter represent a coarsening-upward environment of rapid deposition. According to the methods reported in Selley (1998), the environments of coarsening upward successions can be put into three general categories: (1) regressive barrier bars, (2) prograding submarine fans, (3) prograding deltas or crevasse splays. The first two environments, regressive barrier bars and prograding submarine fans, are commonly deposited with glauconite and shell debris (Selly 1985, 1998; Nelson and James 2000; James and Bone 2000; Chafetz and Reid 2000; Marenssi et al. 2002). Since there is no glauconite and shell debris present in the samples, we may exclude the possibility of the first two environments, and can infer that the paleoenvironment of the funnel-shaped succession with carbonaceous matters belongs to a prograding delta or a crevasse splay. However, one of the main differences between a prograding delta and a crevasse splay is the deposition scale, the prograding delta is comparatively large. Although the area covered by these wells is not more than $6 \mathrm{~km}^{2}$, the accumulated sandstone thickness of the thick funnel-shaped successions is $30 \sim 55 \mathrm{~m}$ in the Hsinyin area and is $28 \sim 32 \mathrm{~m}$ in the Pachanchi area. In view of the sandstone thickness, it is reasonable to infer that the paleoenvironment of the thick funnel-shaped successions is a sedimentary model of a prograding delta. The thick funnel-shaped gamma-ray 
$\operatorname{logs}$ of Sections 1 and 2 in the wells of the Hsinyin area and that of Section V of Wells P-5 and P-6 in the Pachangchi area mostly represent prograding deltas.

\subsection{Thin Funnel-shaped Successions}

\subsubsection{Description}

In the Hsinyin area (Fig. 2), a thin funnel motif recurs in the gamma-ray logs of Section 3 of Wells S-2, S-5 and S-6 and in those of Section 4 of Well S-1, S-5, S-6 and S-7. The thickness of the thin funnel profiles is mostly less than five meters. In the Pachanchi area (Fig. 3), the gamma-ray log of Section II in Well P-5 appears as a thin funnel motif (thickness less than $8 \mathrm{~m}$ ) and there is carbonaceous matters reported in the well report. The gamma-ray log of the sandstone body in Section IV of Wells P-5 and P-6 takes the shape of a set of thin funnel motifs (less than $8 \mathrm{~m}$ ) plus a set of bell motifs (fining up). The bell motif will be discussed in detail later.

\subsubsection{Interpretation}

Similar to the above thick funnel-shaped gamma-ray log motif, reasoning can be used to deduce that the thin funnel motif also indicates the deposition of coarsening or cleaning upwards of thin sediments. According to the identification system of Selly $(1985,1998)$, the paleoenvironment of funnel-shaped successions with carbonaceous detritus can be identified as a prograding delta or a crevasse splay. The thickness of all of the thin funnel-shaped successions is less than 8 meters, which allow us to narrow down the identification of the paleoenvironment to a crevasse splay of a deltaic channel. Less than eight meters seems too thin to be of a prograding delta.

\subsection{Boxcar-shaped Successions}

\subsubsection{Description}

In the Hsinyin area (Fig. 2), the gamma ray logs of the upper and lower boundaries of Section 3 in Wells S-1, S-4 and S-7 are concave (inside). The boxcar motif is formed due to the presence of shales at these two boundaries. The thickness of the boxcar motifs in all the studied intervals is less than 10 meters. According to well reports, the lithologies of these sections are mostly sandstones. In the Pachanchi area (Fig. 3), the boxcar shaped gamma-ray log recurs in Section I of Wells P-5 and P-6 and in Section II of Wells P-6 and P-8 (thickness less than 3 meters) and in Section III of Wells P-5 and P-6 (thickness less than 5 meters). Carbonaceous matter is also present in the successions.

\subsubsection{Interpretation}

The boxcar shaped gamma-ray log indicates the truncation or rapid termination of deposition at the upper and bottom boundaries. Three general categories of environments can de- 
posit boxcar-shaped successions (Selly 1985, 1998). These three environments are tidal sand wave, grain flow fill and delta distributary channel. The first two environments, tidal sand wave and grain flow fill commonly deposit with glauconite and shell debris (Nelson and James 2000; James and Bone 2000; Chafetz and Reid 2000; Marenssi et al. 2002). Only the delta distributary channel associates with carbonaceous detritus. Therefore, the boxcar shaped gammaray $\log$ with carbonaceous detritus indicates a deltaic distributary channel, according to the well $\log$ identification system of Selly $(1985,1998)$. A distributary channel is an irregular, divergent stream flowing away from the main stream in a delta. Distributary channels are often choked by stream deposition and produce new distributary channels. This is the reason that a distributary channel has boxcar shaped gamma-ray log. The sandstone thickness of Section I in Well P-8 is less than those of Wells P-5 and P-6. This may be the distance between Well P-8 and Wells P-5 and P-6 is as far as $9 \mathrm{~km}$, because the sandstone body in this section of Well P-8 may have been eroded, or because the sand bodies in that section in different wells belong to different distributary channels. In Section III of Wells P-5 and P-6, the gamma ray logs also have boxcar shapes and carbonaceous detritus which point to a distributary channel paleoenvironment, but the logs in Section III of Well P-8 have no boxcar shapes or other distinctive features. It is possible that the channel flowing through Well P-5 and P-6 did not pass through Well P-8.

\subsection{Bell-shaped Successions}

\subsubsection{Description}

The gamma-ray log in Section IV of Wells P-5 and P-6 in the Pachanchi area appears to show a bell motif above a thin funnel motif. Carbonaceous detritus is found in the deposits of bell-shaped successions.

\subsubsection{Interpretation}

The bell shaped succession usually occurs in three types of environments: tidal channels, turbidite fills and fluvial or deltaic channels. Tidal channels and turbidite fills also commonly include glauconite and shell debris (Nelson and James 2000; James and Bone 2000; Chafetz and Reid 2000; Marenssi et al. 2002). The only bell shaped successions with carbonaceous detritus are deposited in environments of fluvial or deltaic channels (Selly 1985, 1998). The bell motif above the thin funnel motif of Section IV in Wells P-5 and P-6 reveals the finingupward fill of a fluvial or deltaic channel, indicating a fluvial or deltaic channel (bell motif) lies on top of a crevasse splay (thin funnel motif) in Section IV of Wells P-5 and P-6.

\section{DEPOSITIONAL MODEL FOR THE “A” MEMBER OF THE ERCHUNGCHI FORMATION}

The above interpretations of a prograding delta, crevasse splay and delta distributary channel in the Hsinyin area are all in a small-scale delta system. The crevasse splay of Section 4 is part 
of a deltaic plain. The sandstones of Sections 1, 2 and 3, total thickness of 33 74 m, are delta front sands. The thickest lobe (Fig. 2) in the prograding delta is located in Well S-1 (74 m) and the lobe becomes gradually thinner to the east, Wells S-5 $(51 \mathrm{~m})$ and Well S-4 $(36 \mathrm{~m})$, and to the west, Well S-6 $(53 \mathrm{~m})$ and Well S-2 $(12 \mathrm{~m})$. The paleoenvironment of the corresponding part of the Erchungchi "A" Member in the Pachanchi area is mainly a distributary channel with a thickness of 3 10 m. A fault system with a southwesterly strike, in which "A" Fault has the largest fault throw in the Hsinyin and Pachanchi areas, is a likely cause of the paleoenvironment change seen in the Erchungchi "A" Member in the two areas. The Erchungchi "A" Member onlaps the boundary of the Erchungchi and Kanhsialiao Formations that updip from south to north. This results in the Erchungchi " $A$ " Member having been deposited at different stratigraphic levels in the two areas. This is the reason why the lithologies of the Erchungchi "A" Member of the Hsinyin and Pachanchi areas cannot be correlated.

A possible delta sedimentary model (Fig. 4), derived from the log facies study, demonstrates that the paleoenvironment of the Erchungchi "A" Member in the Hsinyin area is a delta complex. In addition, the effect of "A" Fault on the Hsinyin area can be seen in seismic section (Fig. 5). It is apparent that there are progradation phenomena under the "A" Fault scarp, indicating a prograding delta. This is likely evidence of a delta under the "A" Fault scarp. The

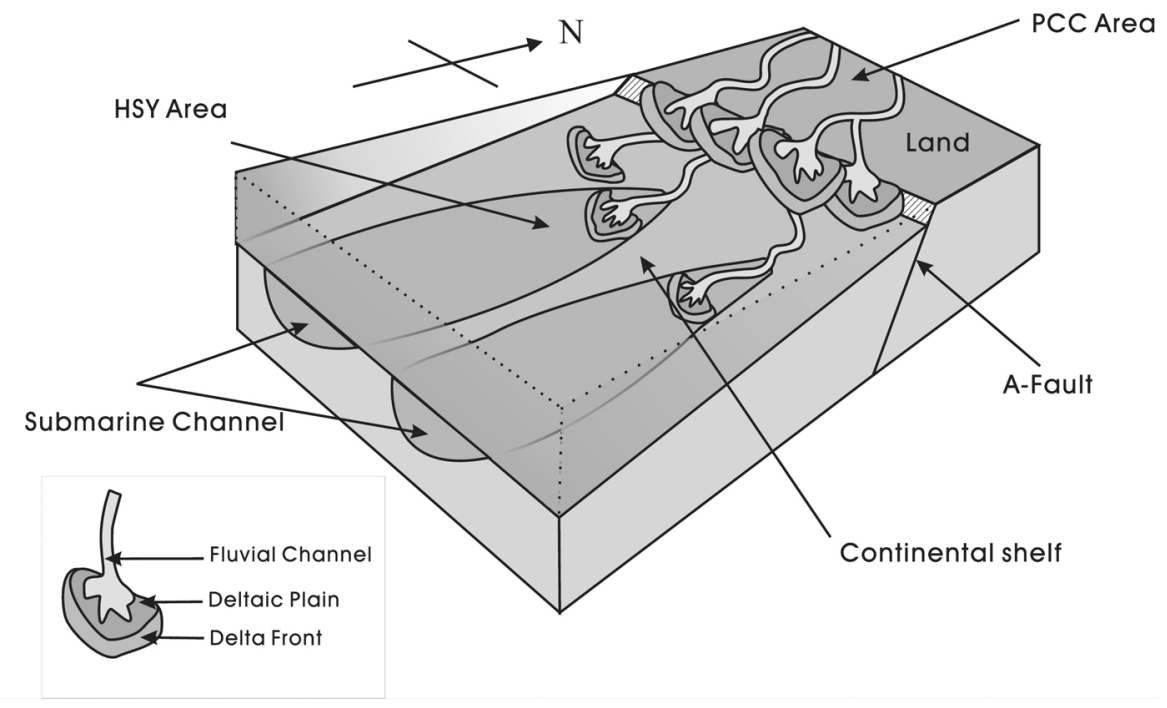

Fig. 4. Schematic diagram of depositional model in Erchungchi "A" Member. The paleoenvironments of the Pachanchi (PCC) area in the north are mainly delatic or fluvial channels, while the sedimentary environment of the Hsinyin (HSY) gas field is a delta system deposited in the submarine channel. The mudstones of the submarine channel serve as both source rocks and cap rocks. 
(a)

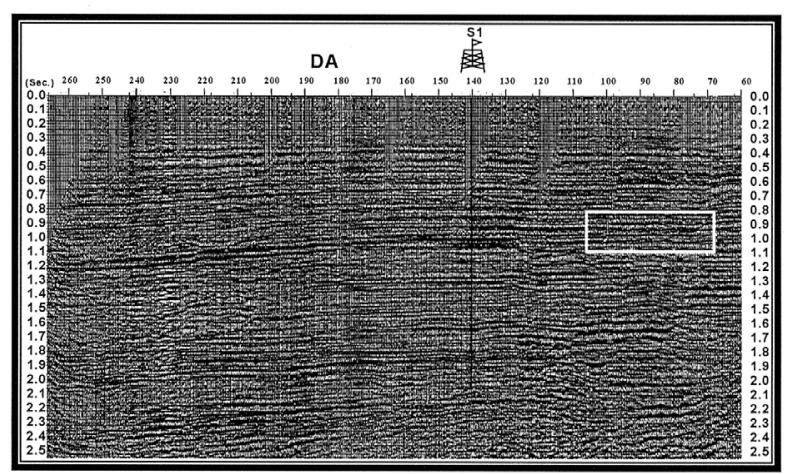

(b)

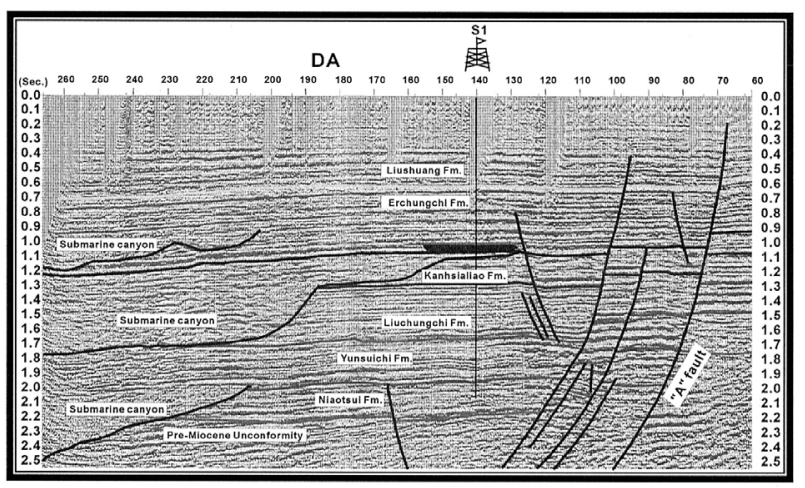

(c)

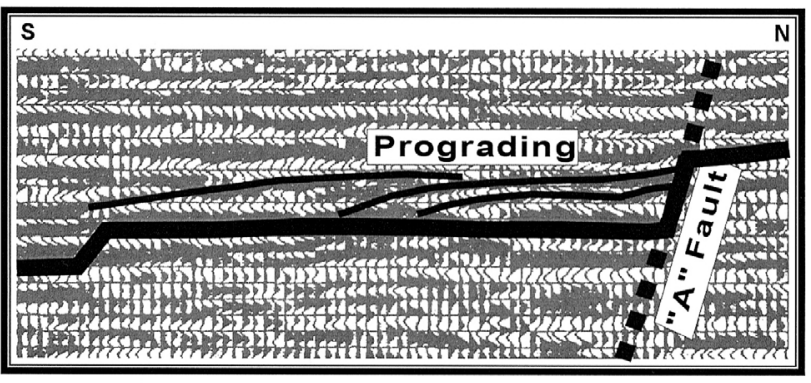

Fig. 5. (a) Uninterpreted section, location see Fig. 1, the rectangular block is enlarged in Fig. 5(c). (b) Interpreted section, The fault throw can be seen in seismic section crossing "A" Fault. A submarine channel developed in the period of Kanhsialiao Fm. and Erchungchi Fm. in the south. The indication of gas at shot point 125 156 and 1.0 second is located in the thin sand bed at the base of Erchungchi "A" Member and above the submarine channel of Kanhsialiao Fm. (c)There is a prograding facies resulting from the small-scale delta under the "A" Fault scarp. 
submarine channel infills the Kanhsialiao Formation and can be seen in seismic section (Fig. 5) and the Erchungchi "A" Member being studied is deposited in the head area of the submarine channel. We deem that the Erchungchi "A" Member in the Hsinyin area was deposited in the submarine channel and that mudstone packed the submarine channel, covering the sandstone set. This process led to an excellent seal for hydrocarbon preservation. The sealing capacity of the mudstone can be recognized in the lithologies of Wells S-1, S-4, and S-5 (Fig. 2).

\section{DISCUSSIONS}

Chow et al. $(1986,1987)$ studied the seismic data of the Houpi-Hsinyin area to reveal submarine channels of different stages which truncate the sediments of the Pliocene-Pleistocene formations. Fuh et al. (1986) conducted seismic modeling research on the Hsinyin hydrocarbon play, and suggested that this was a stratigraphic rather than structural trap.

This study suggests the paleoenvironment of the Erchungchi "A" Member in the Hsinyin area is a delta system located on the headstreams of submarine channels. The fill of the submarine channels is mostly organic-rich muddy sediments. Organic-rich sediments will give off large amount of biogenic methane when decomposed by bacteria in the shallow subsurface (Boussafir and Lallier-Verges 1997). The muddy sediments deposited in the submarine channels may be the kerogen source of the hydrocarbons in the Hsinyin gas field, and the sandstone body of the Erchungchi "A" Member may serve as a good hydrocarbon reservoir. During the transgression process, muddy sediments covered the sandstone body and formed a shale about 25 meters thick, sealing the generated hydrocarbons.

Chow et al. $(1986,1987,1988)$ and Fuh et al. $(1996,1997,2003)$ suggested that submarine channels were widely distributed in southwestern Taiwan and deeply cut the PliocenePleistocene formations. As in the Hsinyin gas field, these submarine channels were filled by mudstones. The mudstones would cap the migration of the generated hydrocarbons, and, moreover, the mudstone is a good kerogen source. So in southwestern Taiwan, shallow strata analogous to delta systems located on submarine channels will be promising locations to find new gas fields in the future.

\section{CONCLUSIONS}

There are four log facies recognized in the well logs of the Hsinyin area. Facies study indicates paleoenvironments of prograding delta, crevasse splay and distributary channels which belong to parts of a deltaic system.

The Erchungchi "A" Member appears at different stratigraphic levels as it overlaps the boundary between the Erchungchi Formation and the Kanhsialiao Formation. The boundary dips upward from south to north. The fault system in this area, in particular "A" Fault, is the likely reason for the difference in the paleoenvironments of the Hsinyin and Pachanchi areas.

The paleoenvironment model based on log and seismic data reveals a delta system in the Erchungchi "A" Member of the Hsinyin area. The delta deposited in the submarine channel before the sand set was effectively sealed by mudstone. This process led to the preservation of 
hydrocarbons in the delta sandstone.

Since many submarine channels exist in southwestern Taiwan, some additional stratigraphic traps analogous to the Hsinyin gas field may occur in the area.

Acknowledgments The authors would like to thank Dr. W. S. Chen for his helpful discussions in a field trip to the Tsengwenchi River. We sincerely thank Prof. Andrew Lin of National Central University and another anonymous reviewer for very valuable suggestions. This research was supported by the Petroleum Foundation, Ministry of Economic Affairs through grant 91-F0103-4. We appreciate the permission of the Petroleum Foundation and Chinese Petroleum Corporation to publish the research results of the grant.

\section{REFERENCES}

Arz, J. A., 2001: Micropaleontology and sedimentology across the Cretaceous/Tertiary boundary at La Ceiba (Mexico): Impact-generated sediment gravity flows.J. South Am. Earth Sci., 14, 505-519.

Bischke, R. E., 1994: Interpreting sedimentary growth structures from well log and seismic data (with examples). Am. Assoc. Petroleum Geol. Bull., 78, 873-892.

Boussafir, M., and E. Lallier-Verges, 1997: Accumulation of organic matter in the Kimmeridge Clay Formation (KCF): an update fossilisation model for marine petroleum sourcerocks. Mar. Petroleum Geol., 14, 75-83.

Bourquin, S., C. Rigollet, and C. Bourges, 1998: High-resolution sequence stratigraphy of an alluvial fan-fan delta environment: Stratigraphic and geodynamic implications - An example from the Keuper Chaunoy Sandstones. Paris Basin. Sediment. Geol., 121, 207-237.

Chafetz H. S., and A. Reid, 2000 : Syndepositional shallow-water precipitation of glauconitic minerals. Sediment. Geol., 136, 29-42.

Chang, S. S. L., 1962: Nomenclature of the Liushuang Formation.Proc. Geol. Soc.China, 1, 189-192.

Chi, W. R., 1982: Calcareous nannoplankton biostratigraphic study and correlation of the late Neogene sequence in the Chiayi and Hsinying foothills, southern Taiwan. Bull. Explor. Prod. Res., 5, 13-38. (in Chinese)

Chow, J., J. W. Yuan, and K. M. Yang, 1986: Geological interpretation of the seismic data in the Houpi area, Tainan. Petroleum Geol. Taiwan, 22, 27-53.

Chow, J., K. M. Yang, and H. M. Chen, 1987: Structural trapps of the Paiho area, southern Taiwan. Petroleum Geol. Taiwan, 23, 13-39.

Chow, J., K. M. Yang, and H. M. Chen, 1988: Seismic interpretation of the subsurface structures in the Yichu-Chiali area, southern Taiwan. Petroleum Geol. Taiwan, 24, 60-95.

Daniels, J. J., G. R. Olhoeft, and J. H. Scott, 1983: Interpretation of core and well log physical property data from drill hole UPH-3, Stephenson County, Illinois ( Illinois Deep Hole Project, USA). J. Geophy. Res., 88, 7346-7354. 
El-Gendy, N. H., and A. El-Din Saleh, 1988: Qualitative well log interpretation of some Early Cretaceous formations in Sidi Abdel Rahman area.Delta J. Sci., 12, 161-190.

Fuh, S. C., M. S. Wu, and T. H. Hsiuan, 1996: Seismic characters of subtle stratigraphic traps in Plio-Pleistocene Erchungchi formation, south of Taiwan: application for evaluation of hydrocarbon potential of future prospects. Petroleum Geol. Taiwan, 30, 151-161.

Fuh, S. C., C. S. Liu, and M. S. Wu, 1997: Migration of submarine channel systems from Pleistocene in area between Hsyning structure and Kaoping slop and its application for hydrocarbon exploration. Petroleum Geol. Taiwan, 31, 43-60.

Fuh, S. C., S. C. Liang, and M. S. Wu, 2003: Spatial and temporal evolution of the PlioPleistocene submarine submarine channels between Potzu and Tainan, Taiwan.Petroleum Geol. Taiwan, 36, 1-18.

Ho, C. S., 1976: Foothills tectonics of Taiwan. Geol. Surv. Taiwan Bull., 25, 9-28.

Hong, C. S., 1991: Study of magnetic minerals and magnetostratigraphy of the Tsengwenchi and Erhjenchi sections, southwestern Taiwan. Ph.D. Dissertation, Nat. Taiwan Univ.. (in Chinese)

Huang, T., 1984: Planktonic foraminiferal biostratigraphy and datumplanes in the Neogene sedimentary sequence in Taiwan. Palaeogeogr., Palaeoclimt., Palaeoeco., 46, 97-106.

Huang, T. Y., 1987: Late Neogene planktonic foraminiferal biostratigraphy of the Tainan, Taiwan. Sci. Devel. Mon. Pub., 9, 1141-1154. (in Chinese)

James N. P., and Bone Y., 2000 : Eocene cool-water carbonate and biosiliceous sedimentation dynamics, St Vincent Basin, South Australia. Sediment., 47, 761-786

Kessler, I. L. G., and S. D. Sachs, 1995: Depositional setting and sequence stratigraphic implications of the Upper Sinemurian (Lower Jurassic) sandstone interval, North Celtic Sea/St George's Channel Basins, offshore Ireland. In: P. F. Croker (Ed.), The petroleum geology of Ireland's offshore basins. Geol. Soc., London, Spec. Pub., 93, 171192.

Lin, A. T., 1991: Lithofacies and the sedimentary environment evolution of the Plio-Pleistocene series in the southwest Taiwan. Msc. Dissertation, Nat. Taiwan Univ. (in Chinese)

Marenssi S. A., L. I. Net, and S. N. Santillana, 2002: Provenance, environmental and paleogeographic controls on sandstone composition in an incised-valley system: the Eocene La Meseta Formation, Seymour Island, Antarctica. Sediment. Geol., 50, 301-321

Milana, J. P., 2000: Characterization of alluvial bajada facies distribution using TM imagery. Sediment., 47, 741-760.

Murkute, Y. A., 2001: Kamthi sandstones: Grain size distribution and depositional processes. J. Geological Soc. India, 58, 435-440.

Nelson C. S., and James N. P., 2000 : Marine cements in mid-Tertiary cool-water shelf limestones of New Zealand and southern Australia. Sediment., 47, 609-629.

Prensky, S. E., 1989: Gamma-ray well-log anomaly in the northern Green River Basin of Wyoming. US Geol. Surv. Bull., 1886, 1-21.

Saner, S., and W. M. Abdulghani, 1995: Lithostratigraphy and depositional environments of the Upper Jurassic Arab-C carbonate and associated evaporites in the Abqaiq Field, eastern Saudi Arabia. Am. Assoc. Petroleum Geol. Bull., 79, 394-409. 
Selley, R. C., 1978a: Ancient sedimentary environments, second edition. London, Chapman \& Hall, $287 \mathrm{pp}$

Selley, R. C. 1978b: Concepts and methods of subsurface facies analysis. Short course and methods of subsurfaces facies analysis. Short course lecture note series, No. 6. Am. Assoc. Petroleum Geol., 80 pp.

Selley, R. C. 1985: Elements of petroleum geology. W. H. Freeman and company, New York, 448pp.

Selley, R. C., 1998: Elements of petroleum geology. Department of Geology, Imperial College, London United Kingdom, 37-145.

Shieh, K. S., and T. Y. Huang, 1991: Sequence stratigraphy of the Pliocene series in the Chailiao area, Tainan, Taiwan. The Second Conf. Taiwan Stratigr., 18-19. (in Chinese)

Wonham, J. P., S. Jayr, R. Mougamba, and P. Chuilion, 2000: 3D sedimentary evolution of submarine channel fill (lower Miocene age) from the Mandorove Formation, offshore Gabon. Mar. Petroleum Geol., 17, 175-197.

Wu, J. C., 1984: Biostratigraphy and paleoenvironments of the Tsengwenchi section in Taiwan. Bull. Explor. Prod. Res., CPC., 7, 33-51. (in Chinese)

Wu, L. C., and Y. Wang, 1989: Depositional environments of the upper Miocene to lower Pleistocene series in the Yunshuichi section, Chia Yi area, Taiwan. Ti-Chih, 9, 15-44. (in Chinese)

Yang S. S., and E. Hong, 1994: The sedimentary environments of the Plio-Pleistocene series in the Liushuang-Chailiao area, southwestern foothills of Taiwan based on lithofacies anaysis. Spec. Pub. Central Geol. Surv., 8, 41-63. (in Chinese) 